\title{
A Study on the Relationship between Banyuwangi Government Policy Mall Orang Sehat Mall of Health People with the Acceptance of the Coronavirus Disease 2019 Vaccine in Indonesian - Implications for Vaccination Implementation Policies
}

\author{
Akhmad Yanuar Fahmi Pamungkas ${ }^{1 *}$, Desi Trianita ${ }^{2}$, Fransiska Erna Damayanti ${ }^{3}$, Ani Qomariyah ${ }^{4}$, Leny Eka Tyas Wahyuni ${ }^{5}$ \\ Badrul Munif ${ }^{3}$, Wahyu Adri Wirawati ${ }^{2}$ \\ ${ }^{1}$ Department of Nursing, Stikes Banyuwangi, Banyuwangi, Indonesia; ${ }^{2}$ Department of Midwifery Science, Stikes Banyuwangi, \\ Banyuwangi, Indonesia; ${ }^{3}$ Department of Nursing Science, Stikes Banyuwangi, Banyuwangi, Indonesia; ${ }^{4}$ Department of Medical \\ Laboratory Technology, Stikes Banyuwangi, Banyuwangi, Indonesia; ${ }^{5}$ Department of Nutrition Science, Stikes Banyuwangi, \\ Banyuwangi, Indonesia
}

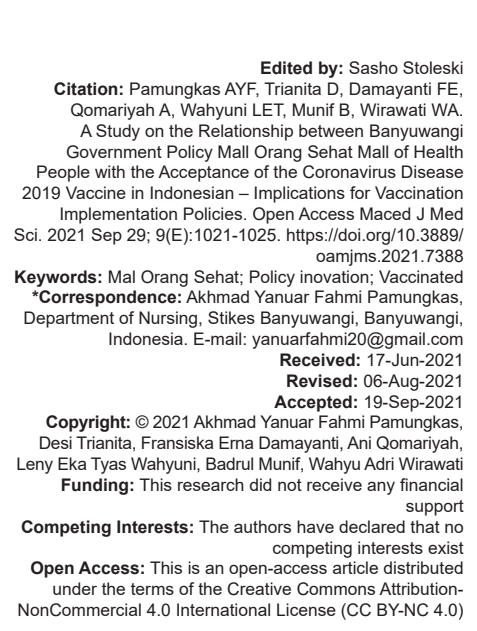

\begin{abstract}
BACKGROUND: The coronavirus disease 2019 (COVID-19) pandemic, caused by severe acute respiratory syndrome coronavirus 2, has caused more than 13 million cases. Until now, there is no very efficient treatment for COVID-19. There needs to be government support in socializing the COVID vaccine, one of which is the Mall Orang Sehat (MOS) innovation for healthy people, which aims to make people believe in vaccines.

AIM: The purpose of this study was to determine the relationship between policy innovations in the MOS area of healthy people and the willingness of the community to be vaccinated.

METHODS: The research method in this study uses a cross-sectional study design, with a sample of 200 using a stratified random sampling technique, with validated question instruments regarding the statement of respondents being willing to be vaccinated or not, the analysis in this study using Chi-square.

RESULTS: The results of this study indicate that there is a relationship between MOS policy innovation and patient's willingness to be vaccinated, as evidenced by the results of SPSS p $0.000<0.05$ which means that there is a relationship between variable 1 and variable 2 .

CONCLUSIONS: The COVID-19 vaccine is the government's effort in tackling the COVID-19 pandemic. With this health education based (Healthy People Mall) it has been proven to be able to influence the public in knowing the effects and impacts of COVID-19 so that people are willing to be vaccinated.
\end{abstract}

\section{Introduction}

The coronavirus disease 2019 (COVID-19) pandemic, caused by severe acute respiratory syndrome coronavirus 2, has caused more than 13 million cases [1]. Until now, there is no very efficient treatment for COVID19 , so the efforts made are prevention efforts such as wearing masks, washing hands, and maintaining social distance [2]. The development of a COVID-19 vaccine which is expected to be a solution to deal with the COVID-19 pandemic, which in the next few years will be the most widely carried out effort [3].

COVID-19 vaccine services are available in various countries, one of which is of concern is the absorption and distribution of vaccines by the public Because this is a new vaccine that needs to use policies to accelerate its spread [4], It is natural for the public to view the safety and effectiveness of the vaccine as a matter of course [5]. This is compounded by the growing phenomenon of doubt about the vaccine process, which is defined as "reluctance or refusal to be vaccinated." [6] And in 2019, the World Health Organization ranked public mistrust about vaccines among the top ten health problems in the world [1]

A study of the acceptance rate of the COVID-19 vaccine found from 33 different countries found that among adults representing the general population, the highest rates of acceptance of the COVID-19 vaccine were found in Ecuador (97.0\%), Malaysia (94.3\%), Indonesia (93.3\%), and China (91.3\%) [7], [8]. However, the lowest rates of acceptance of the COVID-19 vaccine were found in Kuwait (23.6\%), Jordan (28.4\%), Italy (53.7), Russia (54.9\%), Poland (56.3\%), USA (56.9\%), and France. (58.9\%). Only eight surveys among health workers (doctors and nurses) were found, with vaccine 
acceptance rates ranging from $27.7 \%$ in the Democratic Republic of the Congo to $78.1 \%$ in Israel [7].

Education in convincing the public about vaccines needs to be improved because it is one form of handling the COVID-19 problem [9]. Some education that needs to be improved is about the benefits of the COVID-19 vaccine [10], and health risks regarding the effects after the COVID-19 vaccine [11], because it affects people's beliefs or perceptions about vaccines, which means it affects the success of the COVID-19 vaccine.

Stecula's research suggests that people exposed to vaccine-related information on social media are more likely to be misinformed and be hesitant about vaccines [12]. A separate study of 2000 adults in the UK (UK) conducted by the Royal Society for Public Health, found that two-fifths of participants found negative messages about vaccinations on social media platforms [12]. People often share concerns, distrust, and rumors about vaccines on social media before they are detected through traditional surveillance systems, such as event-based surveillance [13]. Therefore, efforts are needed to make this vaccine program a success, including policy innovation programs regarding COVID-19 vaccine education so that people will believe and accept the COVID-19 vaccine [4]. Research Green et al., 2021, shows that education about the benefits of vaccines and government policies regarding mandatory vaccines for Arabs has a significant relationship with trust in vaccines. But in another study, it was stated that government policy on vaccines had no effect on people's willingness to vaccinate [14] and public confidence in vaccines [15]. There needs to be a variation of research comparisons in determining whether there is a relationship between the policies implemented by the government and the success of convincing the public about the COVID-19 vaccine. In 2019, the local government of Banyuwangi, Indonesia, issued a promotive and preventive innovation-based policy, namely Mall Orang Sehat (MOS) MAL Healthy People with the aim of conducting health education to society [16] and in the era of the pandemic the Banyuwangi local government uses this program to conduct education about the COVID 19 vaccine [17]. The purpose of this study was to determine the relationship between the Banyuwangi Mal Orang Sehat regional policy and public trust in the COVID 19 vaccine. This research is important to develop policy innovations to promote the use of vaccines in areas where people do not want to be vaccinated.

\section{Methods}

\section{Study Design}

This study used a cross-sectional study design which was carried out in Banyuwangi Regency, East Java, Indonesia. This study aims to evaluate the health program of the Healthy People Mall on the distribution of the COVID-19 vaccine in Banyuwangi from April to August 2021.

\section{Setting and Sample}

In this study, there were 45 public health centers in the Banyuwangi area, while the sample in this study was 200 people using a stratified random sampling technique with inclusion criteria in this study were Puskesmas that applied the Healthy People Mall regional policy and people who had received health education through Healthy People Mall who are 20 years of age and over.

\section{Instrument}

Participants were asked to fill out a questionnaire containing demographic questions and their attitudes towards the new COVID-19 vaccine. Some are on a Likert scale of 1-5 and others are dichotomous (yes or no). Vaccine-related outcome variables are based on the following questions:

If the Ministry gave the COVID-19 vaccine, would you be willing to be vaccinated.

If the corona virus vaccine is official in Indonesia, are you willing to be vaccinated?

If the number of corona cases continues to increase significantly, are you willing to receive a new vaccine?

\section{Independent variables}

In this study, all the instruments used have been tested for validity and reliability. Characteristics of respondents include age (years), education (no school, elementary, junior high, high school, diploma-3, and undergraduate), employment status (yes or no), and household income per month (Figure 1).

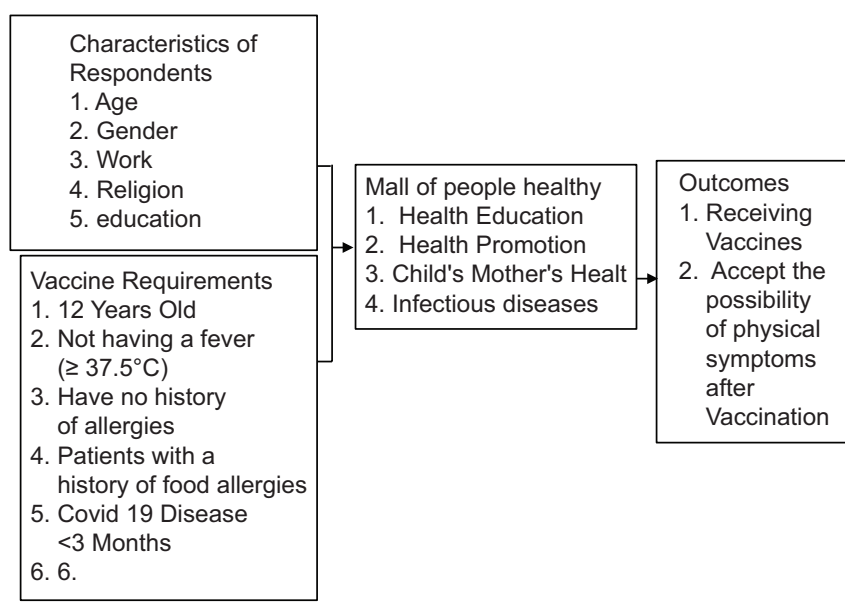

Figure 1: Characteristics of respondents include age (years), education (no school, elementary, junior high, high school, diploma-3, and undergraduate), employment status (yes or no), and household income per month 


\section{Statistical analysis}

This study used descriptive analysis techniques that included percentages with confidence intervals. The prevalence comparisons between groups were performed using the Chi-square test. Multiple logistic regression analysis was used to examine the relationship between the MOS Policy variable and public trust in vaccines. We performed separate regression analyzes for men and women. The study was approved by the ethics committee of the STIKES BANYUWANGI.

\section{Results}

Table 1 shows that the total respondents who participated in this study were 200 people. With an average age of 33.2 years or 33 years, gender was mostly female by 106 respondents and male by 94 respondents. Most of the respondents had education only at the high school level, namely, 67 people. Respondents in this study have a private employee job that is equal to 102 people. Most of the respondents in this study were Muslim.

Table 1: Characteristics or demographic data of respondents

\begin{tabular}{lll}
\hline Characteristics & $\mathrm{n} /$ Total(\%) or mean \pm SD & \\
\hline Total sample & 200 & \\
Gender & & \\
$\quad$ Male & $94 / 200$ & $47 \%$ \\
$\quad$ Female & $106 / 200$ & $53 \%$ \\
Pendidikan & & \\
$\quad$ primary school & $32 / 200$ & $16 \%$ \\
$\quad$ Junior High School & $43 / 200$ & $21,5 \%$ \\
$\quad$ Senior High school & $67 / 200$ & $33,5 \%$ \\
$\quad$ College & $58 / 200$ & $29 \%$ \\
Pekerjaan & $102 / 200$ & \\
$\quad$ Social walker & $20 / 200$ & $51 \%$ \\
$\quad$ Government & & $10 \%$ \\
$\quad$ employees & $52 / 200$ & \\
$\quad$ Housewife & $26 / 200$ & $26 \%$ \\
$\quad$ Student & $189 / 200$ & $13 \%$ \\
Agama & $6 / 200$ & $94,5 \%$ \\
Islam & $2 / 200$ & $3 \%$ \\
$\quad$ Kristen & $3 / 200$ & $1 \%$ \\
$\quad$ Hindu & $33.2 \pm 8.9(20-54)$ & $1,5 \%$ \\
$\quad$ Katolik & & \\
Age & & \\
\hline
\end{tabular}

Table 2 states that most of the male respondents (67 people) and women (99 people) agreed to be vaccinated and after the Chi-square test had a gender relationship with agreeing to be vaccinated. For all types of education, most agree to be vaccinated and have a relationship between the types of education and agree to be vaccinated. For the type of work, most agreed to be vaccinated and there was a relationship between the type of work and agreeing to be vaccinated. All religious adherents in this study agreed to be vaccinated but there was no relationship between religion and agreeing to the vaccine.

Table 3 describes the results of the vaccine approval questionnaire after health education was carried out through MOS (Healthy People Mall). Questions include whether you want to get a COVID-19 vaccine immediately, the majority of which results are
Table 2: Univariate analysis of COVID-19 vaccination acceptability after receiving health education at MOS (healthy people mall)

\begin{tabular}{|c|c|c|c|c|c|}
\hline \multirow[t]{2}{*}{ Characteristics } & \multirow[t]{2}{*}{$\begin{array}{l}\mathrm{n} / \mathrm{Total}(\%) \text { or } \\
\text { mean } \pm \mathrm{SD}\end{array}$} & \multicolumn{3}{|c|}{$\begin{array}{l}\text { Acceptance of COVID } 19 \\
\text { vaccine }\end{array}$} & \multirow[t]{2}{*}{$p$-value } \\
\hline & & $\%$ & Yes & No & \\
\hline Sample & 200 & & & & \\
\hline \multicolumn{6}{|l|}{ Gender } \\
\hline Male & $94 / 200$ & $47 \%$ & 67 & 27 & \multirow[t]{2}{*}{0.000} \\
\hline Female & $106 / 200$ & $53 \%$ & 99 & 7 & \\
\hline \multicolumn{6}{|l|}{ Education } \\
\hline Primary school & $58 / 200$ & $16 \%$ & 48 & 10 & \multirow[t]{4}{*}{0.02} \\
\hline Junior High School & $43 / 200$ & $21,5 \%$ & 38 & 5 & \\
\hline Senior High school & $67 / 200$ & $33,5 \%$ & 49 & 18 & \\
\hline College & $32 / 200$ & $29 \%$ & 31 & 1 & \\
\hline \multicolumn{6}{|l|}{ Work } \\
\hline Social walker & $102 / 200$ & $51 \%$ & 81 & 21 & \multirow[t]{4}{*}{0.03} \\
\hline Government employees & $20 / 200$ & $10 \%$ & 20 & 0 & \\
\hline Housewife & $52 / 200$ & $26 \%$ & 48 & 4 & \\
\hline Student & $26 / 200$ & $13 \%$ & 17 & 9 & \\
\hline \multicolumn{6}{|l|}{ Religion } \\
\hline Islam & $189 / 200$ & $94,5 \%$ & 155 & 34 & \multirow[t]{5}{*}{0.497} \\
\hline Kristen & $6 / 200$ & $3 \%$ & 6 & 0 & \\
\hline Hindu & $2 / 200$ & $1 \%$ & 2 & 0 & \\
\hline Katolik & $3 / 200$ & $1,5 \%$ & 3 & 0 & \\
\hline Age & $33,2 \pm 8,9(20-54)$ & & & 0,973 & \\
\hline
\end{tabular}

respondents agreeing to be vaccinated and have a significant relationship with agreeing to patients. The next question is Do you believe that a pandemic is very dangerous for the public? Most of the results are respondents agree that the corona virus is real and dangerous to society and this question has a very close relationship with agreeing to be vaccinated. The third question is about respondents' trust in vaccines, the result is that most respondents believe the vaccines given are safe for themselves and this question has a very close relationship with agreeing to be vaccinated.

Table 3: Level of confidence in vaccines after receiving health education about vaccines at MOS (Healthy People Mall) based on gender/gender

\begin{tabular}{|c|c|c|c|c|c|}
\hline \multirow[t]{2}{*}{ Variable } & \multirow{2}{*}{\multicolumn{2}{|c|}{$\begin{array}{l}\mathrm{n} / \text { Total }(\%) \text { or mean } \\
\pm \mathrm{SD}\end{array}$}} & \multicolumn{3}{|c|}{ Acceptance of COVID 19 Vaccine } \\
\hline & & & Yes & No & p-value \\
\hline \multicolumn{6}{|c|}{ Q1. Apakah Anda ingin segera mendapatkan vaksin COVID-19? } \\
\hline \multicolumn{6}{|l|}{ Gender } \\
\hline Male & $94 / 200$ & $47 \%$ & 67 & 27 & \multirow[t]{2}{*}{0.000} \\
\hline Female & $106 / 200$ & $53 \%$ & 99 & 7 & \\
\hline \multicolumn{6}{|c|}{ Q2. Apakah Anda percaya bahwa pandemi sangat berbahaya bagi publik? } \\
\hline Gender & & & & & \multirow{3}{*}{0.04} \\
\hline Male & $94 / 200$ & $47 \%$ & 56 & 38 & \\
\hline Female & $106 / 200$ & $53 \%$ & 89 & 17 & \\
\hline \multicolumn{6}{|c|}{ Q3. Apakah Anda Percaya Vaksin itu aman? } \\
\hline \multicolumn{6}{|l|}{ Gender } \\
\hline Male & $94 / 200$ & $47 \%$ & 81 & 21 & \multirow[t]{2}{*}{0.03} \\
\hline Female & $106 / 200$ & $53 \%$ & 20 & 0 & \\
\hline \multicolumn{6}{|c|}{ Q4. Apakah Vaksin itu penting untuk masyarakat } \\
\hline Gender & & & & & \\
\hline Male & $94 / 200$ & $47 \%$ & 67 & 27 & \multirow[t]{2}{*}{0.000} \\
\hline Female & $106 / 200$ & $53 \%$ & 99 & 7 & \\
\hline \multicolumn{6}{|c|}{ Q5. Apakah anda siap dilakukan uji coba setiap vaksin baru } \\
\hline Gender & & & & & \multirow{3}{*}{0.697} \\
\hline Male & $94 / 200$ & $47 \%$ & 40 & 54 & \\
\hline Female & $106 / 200$ & $53 \%$ & 43 & 63 & \\
\hline \multicolumn{6}{|c|}{ Q6. Apakah anda siap di vaksin ketika terjadi peningkatan kasus } \\
\hline Gender & & & & & \\
\hline Male & $94 / 200$ & $47 \%$ & 67 & 27 & \multirow[t]{2}{*}{0.000} \\
\hline Female & $106 / 200$ & $53 \%$ & 99 & 7 & \\
\hline
\end{tabular}

The fourth question is about the importance of vaccines for society, most of the respondents answered that it is important to protect themselves from corona disease. This question has a very close relationship with agreeing to be vaccinated. The fifth question is about people's willingness to be tested for new vaccines, some people are not willing to be tested with vaccines that are not clear from the ministry of health, this question has no relationship with respondents' willingness to be 
vaccinated. The sixth question is are you ready to be vaccinated when there is an increase in cases most of the respondents answered that they are willing to be vaccinated and this question has a close relationship with agreeing to be vaccinated.

\section{Discussion}

This study involved 200 respondents who had been given health education through MOS. There were differences between male and female respondents who took MOS. The number of female respondents are greater than the number of male respondents because the female respondents were more interested in seeking health information than the men. The highest education level is senior high school. Some respondents have interest in seeking health certificates to get jobs. One hundred and two respondents in this study are private sector employees. They are interested in obtaining healthy certificate as a condition for applying a job. Most of the respondents are Muslim.

Most of the male respondents (67 people) and women (99 people) agreed to be vaccinated and after the Chi-square test had a gender relationship with agreeing to be vaccinated. For all types of education, most agree to be vaccinated and have a relationship between the types of education and agree to be vaccinated. For the type of work, most agreed to be vaccinated and there was a relationship between the type of work and agreeing to be vaccinated. All religious adherents in this study agreed to be vaccinated but there was no relationship between religion and agreeing to the vaccine.

This research is supported by research by other studies which state that there is a relationship between gender and agreeing to be vaccinated [6] different from other studies which state that there is no relationship between gender and a person's willingness to receive the vaccine [18]. Men and women have significant differences in something new, including the government's efforts to succeed in vaccines, which is because men prefer to think about side effects than women because women's characters are easy to accept new things.

The results of the vaccine approval questionnaire after health education were carried out through MOS (Healthy People Mall). Questions include whether you want to get a COVID-19 vaccine immediately, the majority of which results are respondents agreeing to be vaccinated and have a significant relationship with agreeing to patients. The next question is do you believe that a pandemic is very dangerous for the public? Most of the results are respondents agree that the corona virus is real and dangerous to society and this question has a very close relationship with agreeing to be vaccinated. The third question is about respondents' trust in vaccines, the result is that most respondents believe the vaccines given are safe for themselves and this question has a very close relationship with agreeing to be vaccinated. The fourth question is about the importance of vaccines for society, most of the respondents answered that it is important to protect themselves from corona disease. This question has a very close relationship with agreeing to be vaccinated. The fifth question is about people's willingness to be tested for new vaccines, some people are not willing to be tested with vaccines that are not clear from the ministry of health, this question has no relationship with respondents' willingness to be vaccinated. The sixth question is are you ready to be vaccinated when there is an increase in cases most of the respondents answered that they are willing to be vaccinated and this question has a close relationship with agreeing to be vaccinated. The above statement is the same as the statement from the previous research that health education [19], [20] can predispose people to vaccines [21]. This statement is supported by previous research on policies that help people to trust vaccines [4], [22]. With the government's policy on health education, MOS (Healthy People Mall) has a role in influencing the community for vaccines.

\section{Conclusions}

The COVID-19 vaccine is the government's effort in tackling the COVID-19 pandemic. With this health education based (Healthy People Mall), it is proven to be able to influence the public in knowing the effects and impacts of COVID-19 so that people are willing to be vaccinated. This program is highly recommended in areas where people refuse to be vaccinated.

\section{References}

1. World Health Organization. Coronavirus Disease 2019. Geneva: World Health Organization; 2020. Available from: https://www. who.int/emergencies/diseases/novel-coronavirus-2019 [Last accessed on 2020 May 30].

2. de Araújo FJ, de Lima LS, Cidade PI, Nobre CB, Neto ML. Impact of sars-Cov-2 and its reverberation in global higher education and mental health. Psychiatry Res. 2020;288:112977. http://doi. org/10.1016/j.psychres.2020.112977 PMid:32302818

3. García LY, Cerda AA. Reply to letter to the editor. Vaccine. 2020;38:7587. http://doi.org/10.1016/j.vaccine.2020.10.026

4. Green MS, Abdullah R, Vered S, Nitzan D. A study of ethnic, gender and educational differences in attitudes toward COVID19 vaccines in Israel implications for vaccination implementation 
policies. Isr J Health Policy Res. 2021;10(1):1-12. http://doi. org/10.1186/s13584-021-00458-w

PMid:33741063

5. Burki T. Equitable distribution of COVID-19 vaccines. Lancet Infect Dis. 2021;21(1):33-34. http://doi.org/10.1016/ S1473-3099(20)30949-X

PMid:33357392

6. Wang J, Jing R, Lai $\mathrm{X}$, Zhang $\mathrm{H}$, Lyu $\mathrm{Y}$, Knoll MD, et al. Acceptance of covid-19 vaccination during the covid-19 pandemic in china. Vaccines. 2020;8(3):1-14. http://doi. org/10.3390/vaccines8030482

7. Sallam M. COVID-19 vaccine hesitancy worldwide: A concise systematic review of vaccine acceptance rates. Vaccines (Basel). 2021;9(2):160. http://doi.org/10.3390/vaccines9020160 PMid:33669441

8. Harapan H, Wagner AL, Yufika A, Winardi W, Sofyan $H$, Mudatsir M. Acceptance of a COVID-19 vaccine in Southeast Asia : A cross-sectional study in Indonesia. 2020;8:381. http:// doi.org/10.3389/fpubh.2020.00381

PMid:32760691

9. Kochhar S, Salmon DA. Planning for COVID-19 vaccines safety surveillance. Vaccine. 2020;38(40):6194-8. http://doi. org/10.1016/j.vaccine.2020.07.013 PMid:32684499

10. Usher AD. COVID-19 vaccines for all? Lancet (London, England). 2020;395(10240):1822-3. http://doi.org/10.1016/ S0140-6736(20)31354-4

11. Kim YC, Dema B, Reyes-Sandoval A. COVID-19 vaccines: Breaking record times to first-in-human trials. NPJ Vaccines. 2020;5(1):34. doi:10.1038/s41541-020-0188-3

12. Stecula DA, Kuru $\mathrm{O}$, Hall Jamieson K. How trust in experts and media use affect acceptance of common anti-vaccination claims. Harvard Kennedy Sch Misinformation Rev. 2020;1(1):111. http://doi.org/10.37016/mr-2020-007

13. Durant $W$. How do we respond to the challenge of vaccine misinformation? Perspect Public Health. 2019;139(6):280-2. http://doi.org/10.1177/1757913919878655

PMid:31686612

14. Salali GD. COVID-19 vaccine hesitancy is associated with beliefs on the origin of the novel coronavirus in the UK and Turkey. 2020;2020:40-2. http://doi.org/10.1017/S0033291720004067 PMid:33070804

15. Sallam M, Dababseh D, Eid H, Al-mahzoum K, Al-Haidar A Taim D. High rates of COVID-19 vaccine hesitancy and its association with conspiracy beliefs: A Study in Jordan and Kuwait among Other Arab Countries. Vaccines (Basel). 2021;9(1):42.

16. Banyuwangi P. Peraturan Bupati Banyuwangi Nomor 37 Tahun 2018 Tentang Pedoman Pelaksanaan aksi Jemput Bola Rawat Warga Kabupaten Banyuwangi Dengan. Vol. 15. 2018.

17. Banyuwangi D. Dinas Kesehatan Banyuwangi Dinas Kesehatan Banyuwangi. Available from: http://dinkes.banyuwangikab. go.id/portal [Last accessed on 2020 Mar 26].

18. Detoc M, Bruel S, Frappe P, Tardy B, Botelho-Nevers E, Gagneux-Brunon A. Intention to participate in a COVID-19 vaccine clinical trial and to get vaccinated against COVID-19 in France during the pandemic. Vaccine. 2020;38(45):7002-6. http://doi.org/10.1016/j.vaccine.2020.09.041

PMid:32988688

19. El-Elimat T, AbuAISamen MM, Almomani BA, Al-Sawalha NA Alali FQ. Acceptance and attitudes toward COVID-19 vaccines: A cross-sectional study from Jordan. PLoS One. 2021;16(4):e0250555. http://doi.org/10.1371/journal. pone. 0250555

PMid:33891660

20. Reiter PL, Pennell ML, Katz ML. Acceptability of a COVID-19 vaccine among adults in the United States: How many people would get vaccinated? Vaccine. 2020;38(42):6500-7. http://doi. org/10.1016/j.vaccine.2020.08.043

PMid:32863069

21. Dal-r R. Placebo-controlled trials with COVID-19 vaccines: Participants first. J Clin Epidemiol. 2021;2021:00211. http://doi. org/10.1016/j.jclinepi.2021.07.004

PMid:34271109

22. Martin S, Arawi T. Correspondence historical evidence to inform COVID-19 access to COVID-19 PREZODE : Preventing. Lancet. 2020;397(10276):791-2. http://doi.org/10.1016/ S0140-6736(21)00190-2

PMid:33640058 